\title{
Records of past ice sheet fluctuations in interior East Antarctica
}

\author{
Xiaohan Liu, ${ }^{1,2}$ Feixin Huang, ${ }^{1}$ Ping Kong, ${ }^{2}$ Aimin Fang, ${ }^{2}$ and Xiaoli $\mathrm{Li}^{2}$ \\ ${ }^{1}$ Institute of Tibetan Plateau Research, Chinese Academy of Sciences, Beijing, 100085, China (xhliu@mail.iggcas.ac.cn) \\ ${ }^{2}$ Institute of Geology and Geophysics, Chinese Academy of Sciences, Beijing, 100029, China
}

\begin{abstract}
The results of a land-based multi-disciplinary study of the past ice surface elevation in the Grove Mountains of interior East Antarctica support a dynamic evolution of the East Antarctic Ice Sheet (EAIS). Moraine boulders of sedimentary rocks and spore pollen assemblage imply a significant shrinkage of the EAIS, with its margin retreating south of the Grove Mountains ( $\sim 450 \mathrm{~km}$ south of recent coast line) before the middle Pliocene. The exposure ages indicate that the ice sheet subsequently re-advanced, with the ice surface rising locally at least $450 \mathrm{~m}$ higher than today. It then went back down constantly from before 2.3 Ma to 1.6 Ma. The glacial topography and existence of soil show that the ice surface fluctuation continued since the early Quaternary, but with highest levels never exceeding $\sim 100 \mathrm{~m}$ higher than today.
\end{abstract}

Citation: Liu, X,, F. Huang, P. Kong, A. Fang, and X. Li (2007), Records of past ice sheet fluctuations in interior East Antarctica: in Antarctica: A Keystone in a Changing World - Online Proceedings of the $10^{\text {th }}$ ISAES, edited by A.K. Cooper and C.R. Raymond et al., USGS Open-File Report 2007-1047, Short Research Paper 106, 4 p.; doi:10.3133/of2007-1047.srp106

\section{Introduction}

A key constraint on our understanding of the East Antarctic Ice Sheet behavior remains the lack of direct land-based evidence of ice sheet surface levels for constraining ice sheet models during known glacial maxima and minima in the post-14 Ma period, when the earth's geography and its climate system had something close to its present character. In this paper, we provide new data from the Grove Mountains, which lie $400 \mathrm{~km}$ inland from the coast of Prydz Bay and rise to $2338 \mathrm{~m}$ (Mt. Harding), protruding hundreds of meters above the contemporary ice surface.

\section{Geographic setting}

The Grove Mountains are a group of 64 isolated nunataks, distributed over an area of $\sim 3200 \mathrm{~km}^{2}\left(72^{\circ} 20^{\prime} \mathrm{S}\right.$ to $73^{\circ} 10^{\prime} \mathrm{S}$, and $73^{\circ} 50^{\prime} \mathrm{E}$ to $75^{\circ} 40^{\prime} \mathrm{E}$ ) in the interior of the EAIS. The regional ice flow direction is toward the northwest, perpendicular to the ridges, away from the central part of the EAIS (e.g. Dome Argus), where the ice surface elevation exceeds 4,050 $\mathrm{m}$ a.s.l. (Figure 1). The nunataks extend along the local equilibrium line, and are responsible for the existence of neighboring blue ice regions. These nunataks expose mainly upper amphibolite to granulite facies metamorphic rocks, syn-orogenic to late orogenic granite, and post tectonic granodioritic aplite and pegmatite.. The absence of active structures and earthquakes, and the lack of Cenozoic volcanism suggest that this region has remained geologically stable since the Late Mesozoic (Liu et al., 2003).

\section{Glacial geology}

The upper parts of the higher nunataks are usually jagged ridges populated with well-developed ventifacts on the summits. The scarcity of glacial erosive imprints, and cavenous weathering features meters deep formed by wind erosion indicate that these higher slopes have been ice free for a long time. But the lower slopes, less than $\sim 100 \mathrm{~m}$ above ice surface have the features of recent glacial erosion. We consider that this regional line

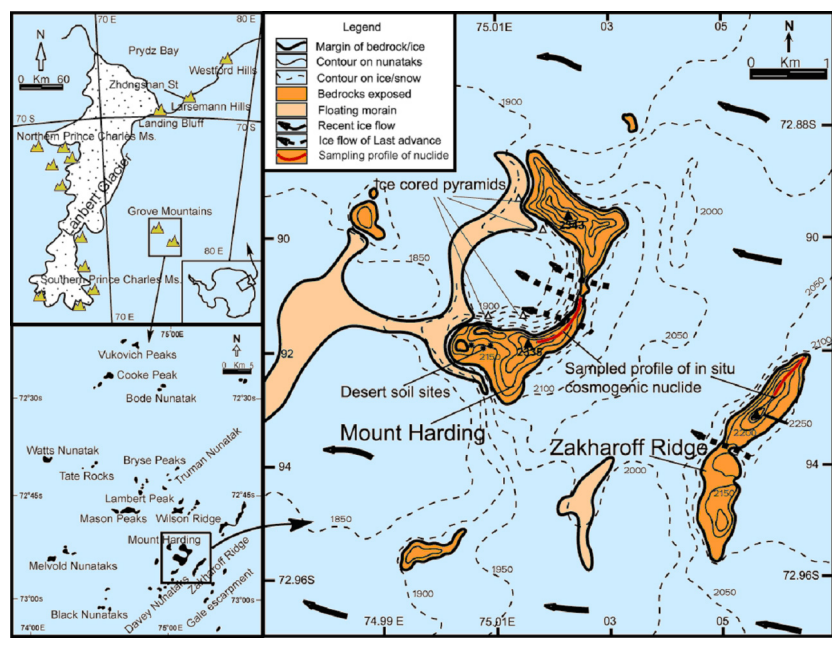

Figure 1. The sketch map showing locality, landscape and ice flow lines in central part of the Grove Mountains.

between wind and glacial erosion could represent a former maximum height of the ice surface during past, probably early Quaternary glaciations.

Mount Harding, in the central part of the Grove Mountains, is a cresent-shaped hill open to the northwest. A stagnant pond of blue ice, tens of $\mathrm{km}^{2}$ wide, lies inside the crescent, having formed since the last regional lowering of the ice surface. An arc-shaped, stadial, icecored moraine $100 \mathrm{~m}$-wide and over $5 \mathrm{~km}$-long, extends along the western edge of this blue ice pond.

\section{Sedimentary boulders}

Besides local rocks, this moraine contains exotic boulders derived from the far southeastern part of interior ice sheet. They include glaciofluvial sedimentary rocks, ophiolites, and meteorites. The sedimentary boulders range from breccias to sandstone, with sandy clay or calcareous cement. In boulders, the shapes of quartz grains in the matrix, grain surface textures and the grain size distribution indicates water transport. We interpret these sediments as of glacial origin formed at the margin 
of a warm-based ice sheet (Fang et al., 2005a). Most of them experienced short transportation by ice flow. All these features suggest that the margin of the EAIS was once located some distance upstream from the Grove Mountains.

The spore-pollen assemblages in these outwash sediment boulders consist not only of typical Nothofagus of the Neogene Weddellian biogeocenose, but also of herbaceous pollen of plants such as Altemisia and Chenopodiaceae (Fang et al., 2005b). These herbaceous plants started to develop since the end of Miocene time, much later than the age of initial formation of a large EAIS. Furthermore, most species within this assemblage survive only in milder climatic conditions, hence it is possible that they were living outboard of the ice sheet front.

The regional context of the Pliocene strata also supports the suggestion of large-scale ice retreat. The Pliocene strata in both the Vestford Hills and Larsemann Hills are mainly marine deposit with deep water foraminifer fossils (Quilty et al., 2000; Harwood et al., 2000). There are fjordal deposits in the northern Prince Charles Mountains (Whitehead and McKelvey, 2000; McKelvey et al., 2001; Hambrey and McKelvey, $2000 \mathrm{a}, \mathrm{b})$. It was reported recently that the sedimentary facies of Pliocene glacial deposits in the southern Prince Charles Mountains was continental facies (Whitehead et al., 2000; Whitehead and McKelvey, 2002), and the corresponding strata in the Prydz Bay was deep water ooze (Barker et al., 1998). The gradual change from deep water to continental facies, from the Prydz Bay, Vestford Hills, Larsemann Hills till to the Prince Charles Mountains show a significant paleo-topographic feature, supporting that the margin of the EAIS was once situated far inside the continent.

\section{Desert soils}

Several cold-desert soil patches were found above the regional erosion limit of $\sim 100 \mathrm{~m}$. The preservation of such soils indicates also that the ice fluctuations have never been higher than this limit after the formation of soils because any higher rise of the ice would have removed them. These soil layers show water laid structures with abundant water-soluble salts, indicating ion transportation in what is currently a frigid and arid environment. Melt-water is required for the formation of soils, while the highest temperature recorded during austral summer in the Grove Mountains is $-10^{\circ} \mathrm{C}$. Therefore, the presence of these soils indicates a warmer climate than at present with some seasonal ice-thawing. Because the soils lack fossils and carbon, the known weathering stages of Antarctic cold desert soils are used as a chronological tool (Campbell and Claridge, 1987). Compared to other Antarctic soils, the soil on Mount Harding formed between 0.5 and 3.5 Ma ( $\mathrm{Li}$ et al., 2003). Despite such a large range of ages, this comparison provides further evidence constraining the age of warmer conditions and the history of local ice surface fluctuations.

\section{Exposure ages}

To use the Grove Mountains as a dipstick of ice fluctuations through time, we sampled bedrock profiles on Zakharoff Ridge (profile A) and on Mount Harding (profile B), for surface exposure dating using in situ cosmogenic nuclide ${ }^{10} \mathrm{Be}$ and ${ }^{26} \mathrm{Al}$. The two sampled slopes are topographically smooth with stable low angles $\left(\sim 3^{\circ}\right.$ in profile $A$ and $\sim 10^{\circ}$ in profile $\left.B\right)$. They are composed of granitic gneiss, with thin foliation lamella parallel to the slope surfaces. The results obtained from Australian Nuclear and Technology Organization (ANTARES, ANSTO), indicate that the ages of simple exposure histories range between late Pliocene to early Quaternary. Figure 2 shows the ${ }^{26} \mathrm{Al} /{ }^{10} \mathrm{Be}$ ratios vs. ${ }^{10} \mathrm{Be}$ concentrations of all 12 samples and Figure 3 shows their minimum ${ }^{10} \mathrm{Be}$ and ${ }^{26} \mathrm{Al}$ exposures ages vs. altitudes. The oldest ${ }^{10} \mathrm{Be}$ and ${ }^{26} \mathrm{Al}$ minimum exposure ages on the crest of Mount Harding ( $\sim 200 \mathrm{~m}$ above recent ice surface) are $2.30 \mathrm{Ma}$ and $1.60 \mathrm{Ma}$ respectively. On the top of Zakharoff Ridge ( $\sim 150 \mathrm{~m}$ above recent ice surface), they are 2.09 Ma and 2.09 Ma respectively. Samples R9204 and R9207 have deviant, older ${ }^{10} \mathrm{Be}$ ages and projected slightly out of the erosion island (Figure 2). If we adopt a smaller value of 5.5 for the ${ }^{26} \mathrm{Al} /{ }^{10} \mathrm{Be}$ ratio (dashed lines in Figure 2) rather than that commonly used 6.1 (solid

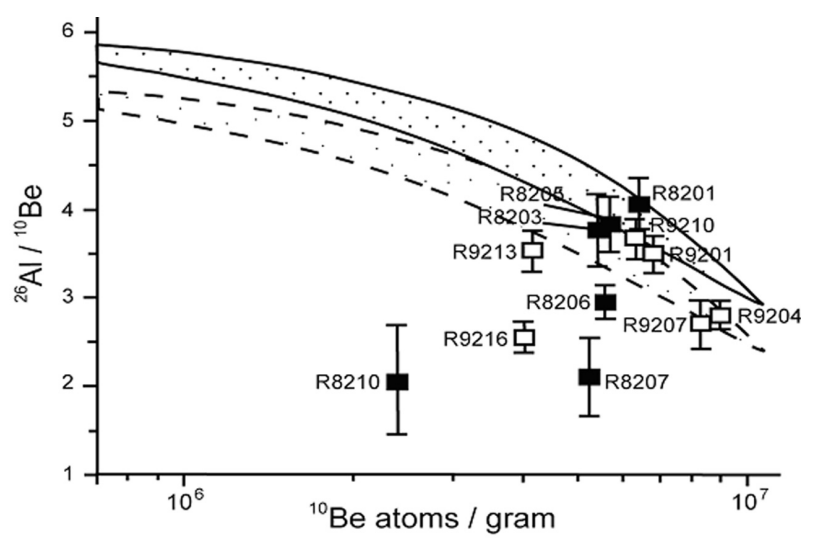

Figure 2. ${ }^{26} \mathrm{Al} /{ }^{10} \mathrm{Be}$ ratios vs. ${ }^{10} \mathrm{Be}$ concentrations.

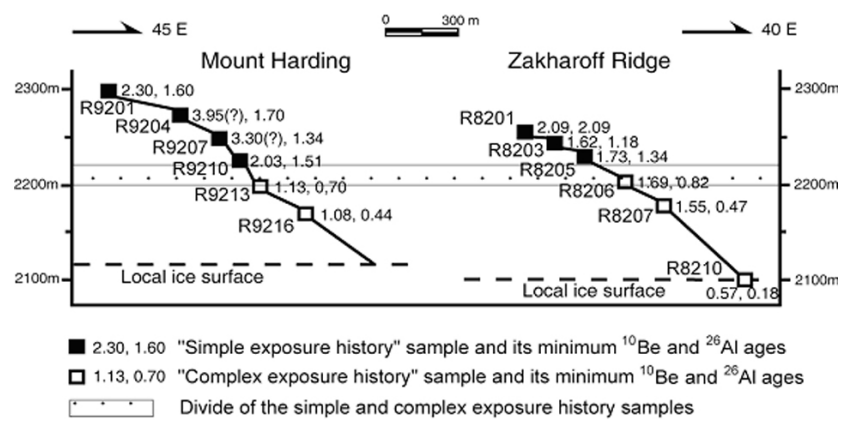

Figure 3. Minimum ${ }^{10} \mathrm{Be}$ and ${ }^{26} \mathrm{Al}$ exposures ages vs. altitudes 
lines), these two samples should project again inside the erosion island.

In the upper part of profile A (higher than erosion limit), the minimum ${ }^{10} \mathrm{Be}$ and ${ }^{26} \mathrm{Al}$ exposure ages diminish downwards till to the Early Pleistocene values (Figure 3). The proportional relationship between the cosmogenic nuclide concentrations and the altitudes of samples of simple exposure histories suggests that the ${ }^{10} \mathrm{Be}$ and ${ }^{26} \mathrm{Al}$ concentrations have not yet reached the secular equilibrium, indicating a steady decrease of the maximum ice surface elevation from the late Pliocene. Furthermore, the oldest ages of the profiles would require that a thick ice cover, at least $250 \mathrm{~m}$, ontop of the summits before the Late Pliocene.

Five samples (R 9213, R 9216, R 8206, R 8207, R 8210) lower than the erosion limit, have undergone real complex exposure histories (Figure 2, 3), which indicates they were lightly shielded from cosmic rays after initial exposure. Therefore the ice surface should have risen again, covering this elevation, perhaps more than once during the Pleistocene. Considering the altitudes of the samples of complex exposure histories, the ice surface in the Grove Mountains might have reached levels lower than the erosion limit during later fluctuations, even during the LGM.

\section{Discussion and conclusions}

Based on geomorphic evidence, inferred ages of soil formation, lithologic analyses of sedimentary boulders, spore pollen assemblages, coupled with in-situ cosmogenic nuclide exposure ages, we suggest that:

1. The margin of the EAIS once lay inland of the Grove Mountains region, some $450 \mathrm{~km}$ south from its present coastal position, before the Late Pliocene. This suggests middle Pliocene warmth (Dowsett et al., 1996).

2. The elevation of the ice surface in the Grove Mountains region subsequently rose to more than at least $450 \mathrm{~m}(200 \mathrm{~m}+250 \mathrm{~m})$ higher than today, before a minimum date of $2.3 \mathrm{Ma}$.

3. The maximum ice surface elevation then progressively descended from $2.3 \mathrm{Ma}$ to $1.6 \mathrm{Ma}$, and suffered small fluctuation since the early Pleistocene. However, the highest level it reached never exceeded $\sim 100 \mathrm{~m}$ above today's level (Figure 4).

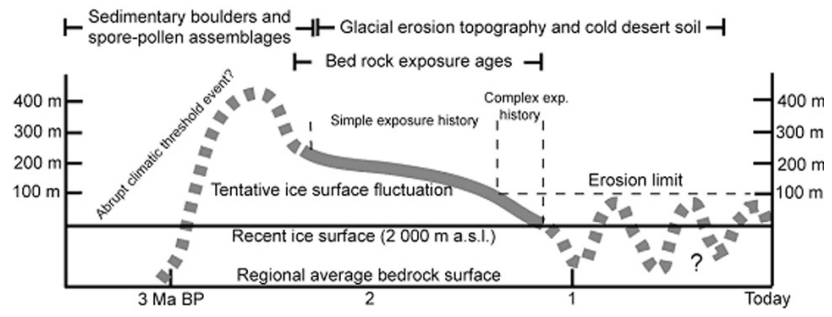

Figure 4. Sketch of tentative history of ice surface fluctuation in the Grove Mountains region

In Figure 4, the bold line represents the ice surface fluctuations through time, the solid line is supported by bed rock exposure ages, and the dashed lines in both left and right parts are inferred based on erosion topographic features and soils. The ice margin retreat, possibly during the middle Pliocene warmth (3.29-2.97 Ma), is based on the sedimentary boulders and their spore-pollen assemblages.

Our results, obtained with a combination of methods, support a dynamic model of the interior EAIS since the Pliocene. The accurate chronology of sedimentary boulders needs to be corroborated by further pollen assemblage studies and the offshore sediment record in Prydz Bay. Even now, our chronological estimation of large scale ice margin retreat of the EAIS adds to evidence obtained otherwise, for example, the ages of volcanic ash bed in diatom-bearing glaciomarine strata cored in Ferrar Fiord by the CIROS drill -hole, the fossil plants from the Pliocene Sirius Group (Barrett et al., 1992; Francis and Hill, 1996), the modeling results of ice sheet variation during the middle Pliocene (Whitehead and McKelvey, 2002), and the deep-sea bottom-water temperatures base on ostracod $\mathrm{Mg} / \mathrm{Ca}$ ratios (Cronin et al., 2005).

Because of the ${ }^{10} \mathrm{Be}$ and ${ }^{26} \mathrm{Al}$ concentrations have not yet reached secular equilibrium in the tops of the 2 cross sections we sampled, it is possible that the highest ice surface level in the Grove Mountains has been still higher, perhaps up to 450 to $500 \mathrm{~m}$ above that of today? The onset of steady descent, which we infer to be at 2.3 $\mathrm{Ma}$, might hence have occurred earlier. Recall that the ${ }^{10} \mathrm{Be}$ and ${ }^{26} \mathrm{Al}$ exposure ages will become older if erosion is taken into account. Overall, our scenario is roughly coeval with climatic events on a global scale, for example the Pliocene is the period when an extensive ice sheet started to form in the northern hemisphere, and the rapid uplift of the Tibetan Plateau took place. The smaller frequent fluctuations of the ice surface during the Quaternary were consistent with the glacial cycles recorded in the northern hemisphere. Our conclusions do not yet consider the regional isostatic correction during the fluctuation history of the ice sheet. Despite the report of Cenozoic up-lift of bed rock in the west side of the Lambert Graben (Hambrey and McKelvey, 2000a,b), we think that there is no evidence of regional tectonics in the Grove Mountains region based on our field investigations.

Acknowledgements. This work was supported by grant of National
Natural Science Foundation of China (40631004), and by grant (kzcx3-
sw-143) from the Chinese Academy of Sciences, and the field logistic
supported by the Chinese Polar Research Administration grants during
1998-2003. We thank Professor Paul Tapponnier and Professor Kenneth
J. Hsü for their constructive comments on our early draft of this
manuscript, and Dr. Philip O'Brien and an anonymous reviewer for their
suggestions. We also thank our co-editor, Dr. Donald Blankenship.

\section{References}

Barker P. F. et al. (1998), Ice sheet history from Antarctic continental margin sediments: the ANTOSTRAT approach. Terra Antarctica, , 5:737-760 
Barrett, P.J., C.J. Adams, W.C. McIntosh, C.C. Swisher and G.S. Wilson (1992), Geochronological evidence supporting Antarctic deglaciation three million years ago, Nature, 359 816-818

Campbell, I.B. and G.G.C. Claridge (1987), Antarctica: Soils, Weathering Processes and Environment, Amsterdam, Elsev. Sci. Pub., $1-368$.

Cronin, T.M., H.J. Dowsett, G.S. Dwyer, P.A. Baker and M.A. Chandler (2005), Mid-Pliocene deep-sea bottom-water temperatures based on ostracode $\mathrm{Mg} / \mathrm{Ca}$ ratios, Marine Micropalaeontology, 54 249-261

Dowsett, H., J. Barron and R. Poore (1996), Middle Pliocene sea surface temperatures: a global reconstruction, Marine Micropaleontology, 27 13-25

Fang, A.M., X.H. Liu, X.L. Li, F.X. Huang and L.J. Yu (2005a), Cenozoic glaciogenic sedimentary record in the Grove Mountains of East Antarctica, Antarctic Science, 17(2) 237-240.

Fang, A.M., X.H. Liu, W.M. Wang, X.L. Li, L.J. Yu and F.X. Huang (2005b), Preliminary study on the spore-pollen assemblages found in the Cenozoic sedimentary rocks in Grove Mountains, East Antarctica and its climatic implications, Chinese Journal of Polar Research, Vol.16, No.1 23-32.

Francis, J.E. and R.S. Hill (1996), Fossil plants from the Pliocene Sirius Group, Transantarctic Mountains: Evidence for climate from growth rings and fossil leaves, Palaios 11 389-396

Hambrey, M.J. and B.C. McKelvey (2000a), Neogene fjordal sedimentation on the western margin of the Lambert Graben, East Antarctica, Sedimentology, 47, 577-607.

Hambrey, M.J. and B.C. McKelvey (2000b), Major Neogene fluctuation of the East Antarctic Ice Sheet, Stratigraphic evidence from the Lambert Glacial region, Geology, 28(10) 887-890.

Harwood D M, et al. (2000) Diatom biostratigraphy and age of the Pliocene Sorsdal formation, Vestfold Hills, east Antarctica, Antarctic Science, 12(4): 443-462.

Li, X.L., X.H. Liu, Y.T. Ju and F.X. Huang (2003), Properties of soils in Grove Mountains, East Antarctica, Science in China (D), 46 (7) 683693.

Liu, X.H., Y, Zhao, X.C. Liu, and L.J. Yu (2003), Geology of the Grove Mountains in East Antarctica-New Evidence for the Final Suture of Gondwana Land, Science in China (D), 46 (4) 305-319.

McKelvey, B.C., M.J. Hambrey, D.M. Harwood (2001), The Pagodroma Group - a Cenozoic record of the East Antarctic ice sheet in the northern Prince Charles Mountains, Antarctic Science, 13 (4), 455-468.

Quilty, P.G., J.M. Lirio, D. Jillett (2000), Stratigraphy of the Pliocene Sorsdal Formation, Marine Plain, Vestfold Hills, East Antarctica, Antarctic Science, 12 (2), 205-216.

Whitehead, J.M. et al. (2000), Cenozoic glacial deposits in the Southern Prince Charles Mountains of East Antarctica. Terra Antarctica, 7(5): 655-656.

Whitehead, J.M., B.C. McKelvey (2001), The stratigraphy of the Pliocene-lower Pleistocene Bard in Bluffs Formation, Amery Oasis, northern Prince Charles Mountains, Antarctica, Antarctic Science, 13 (1), 79-86.

Whitehead, J.M. and B.C. McKelvey (2002), Cenozoic glacigene sedimentation and erosion at the Menzies Range, southern Prince Charles mountains, Antarctica. Journal of Glaciology, 48 (2): 207247. 